\title{
Comparison and Improvement of Different Methods of RNA Isolation from Strawberry (Fragria $\times$ ananassa)
}

\author{
Dingqun $\mathrm{Yu}^{1}$, Haoru Tang ${ }^{1}$, Yong Zhang ${ }^{1}$, Zhen $\mathrm{Du}^{1}$, Haowei Yu ${ }^{1} \&$ Qing Chen ${ }^{1}$ \\ ${ }^{1}$ Horticultural College, Sichuan Agricultural University, Ya'an 625014, Sichuan, China \\ Correspondence: Haoru Tang, Horticultural College, Sichuan Agricultural University, Ya'an 625014, Sichuan, \\ China. Tel: 86-835-288-2293. E-mail: htang@sicau.edu.cn
}

Received: March 2, 2012 Accepted: March 27, 2012 Online Published: May 22, 2012

doi:10.5539/jas.v4n7p51 URL: http://dx.doi.org/10.5539/jas.v4n7p51

The research is financed by Scientific Research Foundation of the Education Department of Sichuan Province, China (09ZB050)

\begin{abstract}
Isolation of high-quality RNA from different strawberry tissues is often affected by the presence of high levels of contamination by polysaccharides and phenolic compounds. By the methods of improved CTAB, SDS, and guanidinium thiocyanate, total RNA was isolated from leaves of strawberry. The result indicated that total RNA is of high quality and undegraded by using CTAB. However, it was difficult to isolate total RNA from leaves of strawberry by using guanidinium thiocyanate, and total RNA could be extracted by using SDS with low concentration, impurity and degradation in some degree. After comparing, an improved $3 \% \mathrm{CTAB}_{3}$ was used to isolate RNA from tissues of strawberry, and the isolated RNA was good enough for further applications. After RT-PCR, the 699 bp sequence of glucose-6-phosphate dehydrogenase (G6PDH) gene was obtained to identify the quality of total RNA from strawberry. In this experiment, improved $3 \% \mathrm{CTAB}_{3}$ method could be regarded as a simple, rapid, economic and convenient method for the RNA isolated from strawberry.
\end{abstract}

Keywords: strawberry, RNA extraction, G6PDH gene

\section{Introduction}

Extraction of RNA of high quantity and quality is an important procedure and can be a limiting factor in plant molecular biology experiments such as Northern blot hybridization, mRNA purification, PCR amplification, cDNA synthesis and cDNA library construction and RNAi (Murillo et al., 1995; Hu et al., 2002; Wang et al., 2006). However, to isolate RNA from some plant tissues is manifestly difficult due to the presence of high amounts of secondary metabolites, such as polysaccharides and polyphenolic compounds, which could co-precipitate or bind to RNA and result in poor yields (Gasic et al., 2004; Djami-Tchatchoua et al., 2011).

Strawberry (Fragaria $\times$ ananassa), a fruit of economic and nutritional importance, is also a model species for soft fruits and genomics in the Rosaceae (Zhang et al., 2011). Its leaves are rich in carbohydrates, pigments and proteins and also contain polyphenols which interfere with RNA isolation in high quantity and quality (Cai et al., 2008). After breaking, strawberry leaf cells release out phenolic compounds leading to the browning effect ( $\mathrm{Li}$, 2001), and oxidation of phenolic compounds could irreversibly bind with RNA causing its loss (Scheiderbauer et al., 1991). Furthermore, this fruit is one of the most complex tissues for RNA isolation (Pandit et al., 2007). Therefore, a reliable method is necessary for the isolation of good-quality RNA from strawberry tissues.

Thompson et al., (2003) used the Plant RNeasy Kit producted by QIAGEN to quickly extract high-quality total RNA from strawberry leaves, but the kit is expensive. Cai et al., (2008) and Yang et al., (2006) extracted RNA from strawberry leaves with the improved CTAB method, but it is time-consuming or contaminates the DNA seriously. The aim of this study was to optimize a simple, rapid, economic and convenient RNA isolation method from strawberry tissues for subsequent experiments.

\section{Materials and Methods}

\subsection{Materials}

Flushing roots, stems, leaves, flowers and mature fruits of strawberry (Fragaria $\times$ ananassa) were obtained from in field-grown plantsat the Sichuan Agricultural University, Sichuan province of China. Tissues were 
immediately frozen in liquid nitrogen and stored at $-80^{\circ} \mathrm{C}$ until needed. Vessels and plastic tubes were dipped in DEPC-treated water overnight and autoclaved. Mortars and pestles were treated with DEPC-treated water, and then baked for $6 \mathrm{~h}$ at $180^{\circ} \mathrm{C}$.

\subsection{RNA Extraction Methods}

\subsubsection{RNA Extraction Protocol}

1. Frozen leaves $(0.1 \mathrm{~g})$ were ground with a mortar and a pestle in the presence of liquid nitrogen and PVPP $(0.01 \mathrm{~g})$.

2. The resulting powder was transferred to a sterile centrifuge tube containing $700 \mu \mathrm{l}$ of pre-warmed $\left(65^{\circ} \mathrm{C}\right)$ extraction buffer. The sample was vortexed vigorously for $1 \mathrm{~min}$ and then incubated at $65^{\circ} \mathrm{C}$ for $10 \mathrm{~min}$ to lyse cells completely.

3. Centrifuging at $15700 \mathrm{~g}$ for $5 \mathrm{~min}$ and transferring the supernatants into a new sterile tube.

4. Adding an equal volume of chloroform: isoamyl alcohol (24:1) mixture extraction (replace mixture by Tris-Phenol in $\mathrm{SDS}_{2}$ method), the tube was vortexed vigorously for $1 \mathrm{~min}$ and centrifuged at $15700 \mathrm{~g}$ for $10 \mathrm{~min}$ at room temperature. After centrifugation, the upper phase was transferred to a new tube.

5. Following the addition of an equal volume of chloroform, the tube was vortexed vigorously for $1 \mathrm{~min}$ and centrifuged at $15700 \mathrm{~g}$ for $10 \mathrm{~min}$ at room temperature.

6. After centrifugation, the upper phase was transferred to a new tube following the addition of an equal volume of $4 \mathrm{M} \mathrm{LiCl}$.

7. After precipitated at $4^{\circ} \mathrm{C}$ for $4 \mathrm{~h}$, the tube was centrifuged $\left(15700 \mathrm{~g}, 15 \mathrm{~min}, 4^{\circ} \mathrm{C}\right)$ and the pellets were washed gently twice with $75 \% \mathrm{EtOH}$.

8. Then the tubes were centrifuge at $5900 \mathrm{~g}$ for $5 \mathrm{~min}$, and resultant pellet was air dried and re-suspended in $30 \mu 1$ DEPC-treated water.

\subsubsection{RNA Extraction Methods}

Different extraction methods were listed in table 1.

Table 1. Different methods

\begin{tabular}{|c|c|c|c|}
\hline Method & extraction buffer & extraction protocol & extraction tissue \\
\hline $3 \% \mathrm{CTAB}_{1}$ & $\begin{array}{c}\text { 3\% CTAB, } 100 \mathrm{mM} \text { Tris-HCl } \mathrm{pH} 8.0,1.4 \\
\mathrm{M} \mathrm{NaCl}, 20 \mathrm{mM} \text { EDTA, 5\%PVP, } 1 \% \\
\beta \text {-mercaptoethanol added just before use }\end{array}$ & $1,2,5,6,7,8$ & leaves \\
\hline $3 \% \mathrm{CTAB}_{2}$ & $\begin{array}{l}\text { the same as } 3 \% \mathrm{CTAB}_{1} \\
4 \% \text { CTAB, } 100 \mathrm{mM} \text { Tris- } \mathrm{HCl} \mathrm{pH} 8.0,1.4\end{array}$ & $1,2,4,5,6,7,8$ & leaves \\
\hline $4 \% \mathrm{CTAB}$ & $\begin{array}{c}\mathrm{M} \mathrm{NaCl}, 20 \mathrm{mM} \text { EDTA, 5\%PVP, } 1 \% \\
\beta \text {-mercaptoethanol added just before use }\end{array}$ & $1,2,5,6,7,8$ & leaves \\
\hline $3 \% \mathrm{CTAB}_{3}$ & the same as $3 \% \mathrm{CTAB}_{1}$ & $1,2,3,5,6,7,8$ & $\begin{array}{l}\text { roots, stems, } \\
\text { leaves, flowers, } \\
\text { mature fruits }\end{array}$ \\
\hline $\mathrm{SDS}_{1}$ & $\begin{array}{c}3 \% \text { SDS, } 100 \mathrm{mM} \text { Tris-HCl } \mathrm{pH} \text { 8.0, } 0.2 \mathrm{M} \\
\mathrm{NaCl}, 20 \mathrm{mM} \text { EDTA, 5\% PVP } \\
\beta \text {-mercaptoethanol added just before use }\end{array}$ & $1,2,5,6,7,8$ & leaves \\
\hline $\mathrm{SDS}_{2}$ & the same as $\mathrm{SDS}_{1}$ & $\begin{array}{l}1,2,4,5,6,7,8 \\
\text { adding the ahove sten } 5\end{array}$ & leaves \\
\hline $\begin{array}{l}\text { Guanidinium } \\
\text { thiocyanate }_{1}\end{array}$ & according to Sambrook et al. (2000) & $\begin{array}{l}\text { adding the above step } 5 \\
\text { before Sambrook's step } \\
8\end{array}$ & leaves \\
\hline $\begin{array}{l}\text { Guanidinium } \\
\text { thiocyanate }_{2}\end{array}$ & according to Sambrook et al. (2000) & $\begin{array}{l}\text { according to Sambrook } \\
\text { et al. (2000) }\end{array}$ & leaves \\
\hline
\end{tabular}




\subsection{Gel Electrophoresis and Analysis of RNA Purity}

3ul RNA samples were detected by $1.0 \%$ agarose gel electrophoresis, $75 \mathrm{~mA}$ for $18 \mathrm{~min}$. Added $5 \mathrm{ul}$ RNA to $45 \mathrm{ul}$ DEPC-treated water, and detected ratios $\mathrm{A}_{260} / \mathrm{A}_{230}$ and $\mathrm{A}_{260} / \mathrm{A}_{280}$.

\section{$2.4 R T-P C R$}

RT-PCR was used to detect the RNA of roots, stems, leaves, flowers and fruits extracted by $3 \% \mathrm{CTAB}_{3}$. The first strand cDNA is synthesized from $1 \mu \mathrm{g}$ of the total RNA by reverse transcriptase with Oligo-(dT) primer according to the instructions of the RevertAidTM First Stand cDNA Synthesis Kit (MBI Fermentas).

Based on the conserved regions of the G6PDH gene nucleotide sequences from Fragaria $\times$ ananassa (JQ260862), the gene-specific primers were designed as follows: G6-F: 5'-AGAGGGA GAATTGTGGTG-3', G6-R: 5'-CAGTGTAGGCTGGGTAAG-3'. PCR was performed with a $25 \mu 1$ reaction mixture containing $2 \mu 1$ of first-strand cDNA, $12.5 \mu 12 \times$ Taq PCR Master Mix (TIANGEN, China), $1 \mu$ l primer G6-F and $1 \mu 1$ primer G6-R, and $8.5 \mu 1 \mathrm{ddH}_{2} \mathrm{O}$.

The PCR procedure started with $94^{\circ} \mathrm{C}$ for $3 \mathrm{~min}$, then 35 cycles of $94^{\circ} \mathrm{C}$ for $1 \mathrm{~min}, 60^{\circ} \mathrm{C}$ for $1 \mathrm{~min}, 72^{\circ} \mathrm{C}$ for $1 \mathrm{~min}$, and finally $72^{\circ} \mathrm{C}$ for $10 \mathrm{~min}$. The PCR products were analyzed on $1.0 \%$ agarose/EtBr gel and the corresponding DNA bands were recovered. Then the PCR products ware sequenced with Big Dye Terminators using ABI-PRISM3730 Sequencer (PE Applied Biosystems, Foster City, California, USA).

\section{Results}

\subsection{Results of Total RNA by $C T A B_{s}, S D S_{s}$, Guanidinium Thiocyanate from Leaves}

By improved CTAB, SDS, and guanidinium thiocyanate methods, total RNA was isolated from strawberry leaves. Total RNA was compared by gel electrophoresis (Figure 1) and the ratio of $A_{260} / A_{280}$ was measured (Table 2). The result indicated that the RNA was of high quality and undegraded, and the sharpness of $28 \mathrm{~S}$ bands was twice than $18 \mathrm{~S}$ of bands using the $3 \% \mathrm{CTAB}_{1}$ compared to the $4 \% \mathrm{CTAB}$ method. The ratio of $\mathrm{A}_{260} / \mathrm{A}_{280}$ was from 1.8 to 1.9 , and ratio of $\mathrm{A}_{260} / \mathrm{A}_{230}$ was higher than 2.0 by two methods. It indicates the results of RNA isolation were basically qualified to the next experiments. The brightness of $28 \mathrm{~S}$ bands was the same to $18 \mathrm{~S}$ bands by using $3 \% \mathrm{CTAB}_{2}$ method. Some RNA lost by procedure of chloroform: isoamyl alcohol (24:1) mixture extracting.

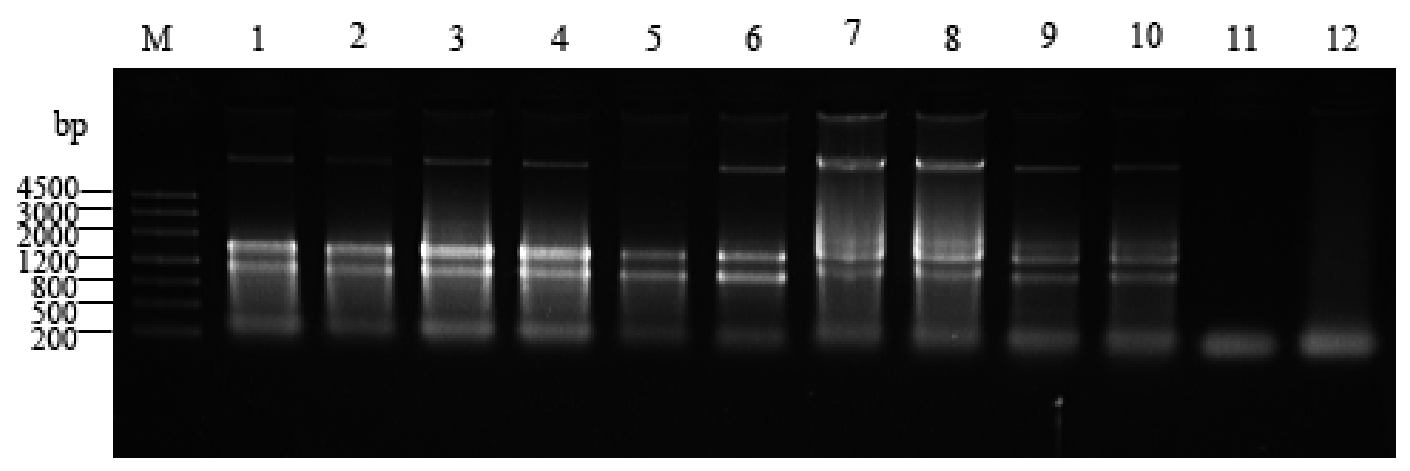

Figure 1. Results of all $\mathrm{CTAB}_{\mathrm{s}}, \mathrm{SDS}_{\mathrm{s}}$, guanidinium thiocyanate $\mathrm{s}$

$\mathrm{M}=$ DNA ladder; lane 1,2 by $3 \% \mathrm{CTAB}_{1}$; lane 3,4 by $4 \% \mathrm{CTAB}$; lane 5,6 by $3 \% \mathrm{CTAB}_{2}$; lane 7,8 by $\mathrm{SDS}_{1}$; lane 9,10 by $\mathrm{SDS}_{2}$; lane 11 by Guanidinium thiocyanate ${ }_{1}$; lane 12 by Guanidinium thiocyanate ${ }_{2}$

Table 2. Purity analysis of total RNA by $\mathrm{CTAB}_{\mathrm{s}}, \mathrm{SDS}_{\mathrm{s}}$ and guanidinium thiocyanate ${ }_{\mathrm{s}}\left(\mathrm{GT}_{\mathrm{s}}\right)$ from leaves

\begin{tabular}{cccccccccccccc}
\hline Absorbance & \multicolumn{3}{c}{$3 \% \mathrm{CTAB}_{1}$} & \multicolumn{2}{c}{$4 \% \mathrm{CTAB}$} & \multicolumn{2}{c}{$3 \% \mathrm{CTAB}_{2}$} & \multicolumn{2}{c}{$\mathrm{SDS}_{1}$} & \multicolumn{2}{c}{$\mathrm{SDS}_{2}$} & $\mathrm{GT}_{1}$ & $\mathrm{GT}_{2}$ \\
\hline $\mathrm{A}_{230}$ & 0.637 & 0.452 & 1.106 & 0.887 & 0.402 & 0.283 & 0.506 & 0.346 & 1.809 & 1.519 & 1.32 & 1.127 \\
$\mathrm{~A}_{260}$ & 1.523 & 0.997 & 2.421 & 2.119 & 0.571 & 0.504 & 0.887 & 0.742 & 1.393 & 1.847 & 0.086 & 0.828 \\
$\mathrm{~A}_{280}$ & 0.802 & 0.539 & 1.343 & 1.115 & 0.456 & 0.258 & 0.467 & 0.410 & 1.330 & 1.488 & 0.041 & 0.714 \\
$\mathrm{~A}_{260} / \mathrm{A}_{230}$ & 2.39 & 2.21 & 2.19 & 2.39 & 1.42 & 1.78 & 1.75 & 2.14 & 0.77 & 1.21 & 1.16 & 0.73 \\
$\mathrm{~A}_{260} / \mathrm{A}_{280}$ & 1.90 & 1.85 & 1.80 & 1.90 & 1.45 & 1.95 & 1.90 & 1.81 & 1.05 & 1.24 & 1.26 & 1.16 \\
\hline
\end{tabular}

However, the results of extracting RNA by $\mathrm{SDS}_{\mathrm{s}}$ and guanidinium thiocyanate $\mathrm{s}_{\mathrm{s}}$ were not satisfactory. It was

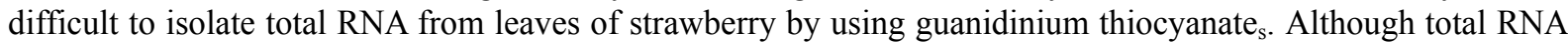
could be extracted by using $\mathrm{SDS}_{1}$ with low concentration, impurity and degradation in some degrees, the 
sharpness of $28 \mathrm{~S}$ bands was no better than $18 \mathrm{~S}$, which indicated that the bands of $28 \mathrm{~S}$ RNA might be degraded. Reasons resulting in these phenomena were some RNase and insoluble substances existing. So some powerful denaturants were required to degrade RNase and get rid of polysaccharides before precipitating.

\subsection{Results of Total RNA Exacting from Tissue by 3\%CTAB 3 Method}

The result of RNA exacting from roots, stems, leaves, flowers and mature fruits of strawberry by $3 \% \mathrm{CTAB}_{3}$ were shown by gel electrophoresis (Figure 2) and the ratio of $A_{260} / A_{280}$ (Table 3). The sharpness of $28 \mathrm{~S}$ bands was twice than $18 \mathrm{~S}$ of bands in all exacting RNA. The ratio of $\mathrm{A}_{260} / \mathrm{A}_{280}$ is above 1.90 , and ratio of $\mathrm{A}_{260} / \mathrm{A}_{230}$ is higher than 2.0. It indicates the results of RNA isolation from roots, stems, leaves, flowers and mature fruits are qualified to the next experiments.

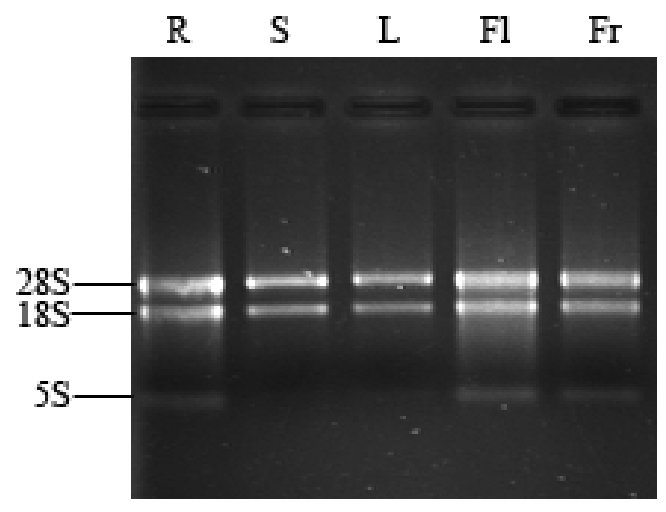

Figure 2. Isolated RNA from different tissue by $3 \% \mathrm{CTAB}_{3}$

M: DNA ladder; R: roots; S: stems; Fl: flowers; L: leaves; Fr: fruits

Table 3. Purity analysis of total RNA from roots, stems, leaves, flowers, fruits by $3 \% \mathrm{CTAB}_{3}$

\subsection{RT-PCR and Sequence Analysis}

\begin{tabular}{cccccc}
\hline Absorbance & roots & stems & flowers & leaves & fruits \\
\hline $\mathrm{A}_{230}$ & 0.372 & 0.263 & 0.292 & 0.637 & 0.351 \\
$\mathrm{~A}_{260}$ & 0.870 & 0.668 & 0.589 & 0.889 & 0.756 \\
$\mathrm{~A}_{280}$ & 0.442 & 0.326 & 0.307 & 0.802 & 0.395 \\
$\mathrm{~A}_{260} / \mathrm{A}_{230}$ & 2.34 & 2.54 & 2.02 & 2.13 & 2.15 \\
$\mathrm{~A}_{260} / \mathrm{A}_{280}$ & 1.97 & 2.05 & 1.92 & 2.17 & 1.91 \\
\hline
\end{tabular}

The RNA isolated from roots, stems, leaves, flowers and mature fruits of strawberry by $3 \% \mathrm{CTAB}_{3}$ are suitable for RT-PCR. By primer G6-F and G6-R and RNA from tissue, PCR amplification generated DNA products with the expected size of about $700 \mathrm{bp}$ (Figure 3). Sequence analysis revealed a PCR product of $699 \mathrm{bp}$ long. The similarity analysis of nucleotide sequence within different plants species revealed that they shared high homology by Blastx (Table 4). The sequence of target gene shared a similarity of the deduced amino acid sequences (91-94\%) with G6PDH genes of other plants, among which it shared the highest sequence homology with castor strawberry. Therefore, we presumed that it was the target fragment and submitted it to GenBank (JQ323094).

Table 4. Results of sequence similarity analysis

\begin{tabular}{llccl}
\hline $\begin{array}{l}\text { Genbank } \\
\text { Accession number }\end{array}$ & Compared gene & Score(bits) & E value & Identities \\
\hline EEF47431.1 & Ricinus communis G6PDH & 415 & $2 \mathrm{e}-146$ & $200 / 215(93 \%)$ \\
XP_003552660.1 & Glycine max G6PDH & 410 & $1 \mathrm{e}-144$ & $202 / 215(94 \%)$ \\
XP_002266930.1 & Vitis vinifera G6PDH & 405 & $5 \mathrm{e}-143$ & $198 / 215(92 \%)$ \\
AED91851.1 & Arabidopsis thaliana G6PDH & 405 & $1 \mathrm{e}-142$ & $196 / 215(91 \%)$ \\
EEE82659.1 & Populus trichocarpa G6PDH & 403 & $7 \mathrm{e}-142$ & $197 / 215(92 \%)$ \\
CAB52708.1 & Solanum tuberosum G6PDH & 400 & $9 \mathrm{e}-141$ & $195 / 215(91 \%)$ \\
\hline
\end{tabular}




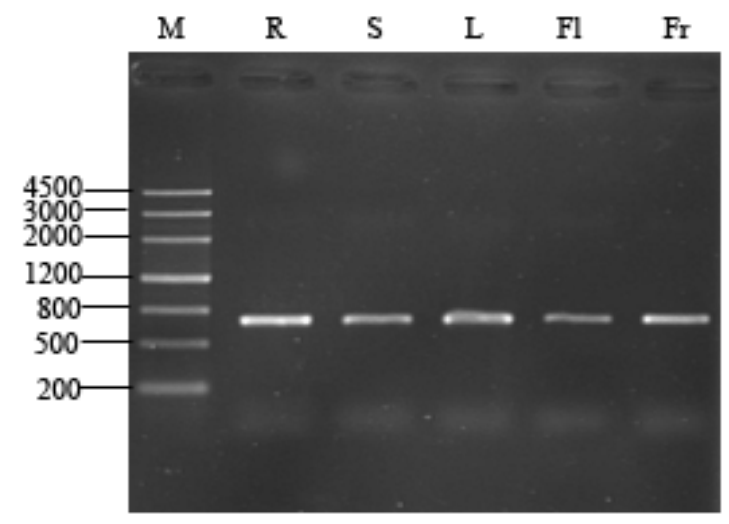

Figure 3. RT-PCR product of tissue

M: DNA ladder; R: PCR product of roots; S: PCR product of stems; L: PCR product of leaves; Fl: PCR product of flowers; Fr: PCR product of fruits

\section{Discussion}

Plant RNA isolation plays an important role in various experiments. To successfully isolate RNA from strawberry, we applied seven different methods $\left(\mathrm{CTAB}_{\mathrm{s}}, \mathrm{SDS}_{\mathrm{s}}\right.$ and guanidinium thiocyanate $\left.{ }_{\mathrm{s}}\right)$ to extract RNA from leaves. Firstly, $\mathrm{CTAB}_{\mathrm{s}}$ were better than $\mathrm{SDS}_{\mathrm{s}}$ and guanidinium thiocyanate $\mathrm{s}$. By $3 \% \mathrm{CTAB}_{1}$ and $4 \% \mathrm{CTAB}$, no RNA degradation was detected and the result was basically free of protein contamination. Although the $3 \%$ $\mathrm{CTAB}_{2}$ method spend much more time and add chloroform: isoamyl alcohol (24:1) mixture to remove proteins, no better quality was obtained. It might be some important RNA loss by mixture extraction. Secondly, RNA isolated from leaves by $\mathrm{SDS}_{\mathrm{s}}$ was not satisfactory. There were lots of insoluble substances existing in RNA. They maybe were some insoluble polysaccharids or proteins. What's more, it was hardly to isolate total RNA from leaves of strawberry when we tried the method of guanidinium thiocyanate by the protocol of Sambrook (Sambrook et al., 2000). Only the 5S RNA band was obtained with some insoluble substances, even though we added chloroform to deal with.

Although a number of different methods have been described for the isolation of plant RNA, in most cases, they involve either the use of detergents SDS or phenol extraction (Logemann et al., 1987; Mazzara and James, 2000; Vasanthaiah et al, 2008). When we tried to apply these methods to the isolation of RNA from strawberry, these methods failed due either to RNA degradation or very low yield. After comparing, we developed a modified $3 \% \mathrm{CTAB}_{3}$ to extract RNA from roots, stems, leaves, flowers and mature fruits of strawberry.

Proved by this experiment, we found that $3 \% \mathrm{CTAB}_{3}$ was appropriate for RNA extracting from tissues of strawberry and total RNA obtained was of sufficient quality to be used for downstream experiments. We successfully obtained G6PDH gene fragment by extracted RNA, and shared a similarity of $91 \%-94 \%$ with $\mathrm{G} 6 \mathrm{PDH}$ genes of other plants. In conclusion, $3 \% \mathrm{CTAB}_{3}$ is efficient to get more RNA and prevent degradation of RNA, and is the best method for RNA purification from strawberry tissues.

\section{References}

Cai, B., Zhang, J., Gao, Z., Qu, S., Tong, Z., Mi, L., Qiao, Y., \& Zhang, Z. (2008). An improved method for isolation of total RNA from the leaves of Fragaria spp. Jiangsu Journal of Agriculture Science, 24(6), 875-877.

Djami-Tchatchoua, A. T., \& Straker, C. J. (2011). The isolation of high quality RNA from the fruit of avocado (Persea americana Mill.). South African Journal of Botany, 78, 44-46. http://dx.doi.org/10.1016/j.sajb.2011.04.009

Gasic, K., Hernandez, A., \& Korban, S. S. (2004). RNA extraction from different apple tissues rich in polyphenols and polysaccharides for cDNA library construction. Plant Molecular Biology Reporter, 22(4), 437-438. http://dx.doi.org/10.1007/BF02772687

Hu, G. C., Honda, C. H., Kita, M. Y., Zhang, Z., Tsuda, T., \& Moriguchi, T. (2002). A simple protocol for RNA isolation from fruit trees containing high levels of polysaccharides and polyphenol compounds. Plant Molecular Biology Reporter, 20(1), 69a-69g. http://dx.doi.org/10.1007/BF02801935

Logemann, J., Schell, J., \& Willmitzer, L. (1987). Improved method for the isolation of RNA from plant tissues. Analytical Biochemistry, 163(1), 16-20. http://dx.doi.org/10.1016/0003-2697(87)90086-8 
Li, D. (2001). The method of extracting total RNA from plants with plenty of secondary products. Journal of Nanjing University of Science and technology, 25(5), 547-549.

Murillo, I., Raventos, D., Jaeck, E., \& San Segundo B. (1995). Isolation of total RNA and mRNA from plant tissues, Promega Notes Magazine, 54, 2-7.

Mazzara, M., \& James, D. J. (2000). The influence of photoperiodic growth condition on isolation of RNA from strawberry (Fragaria $\times$ ananassa Duch.) tissue. Molecular biotechnology, 15(3), 237-241. http://dx.doi.org/10.1385/MB:15:3:237

Pandit, S. S., Mitraz, S. S., Giri, A. P., \& Gupta V. S. (2007). A quick method for isolating RNA from raw and ripe fleshy fruits as well as for co-isolating DNA and RNA from polysaccharide and polyphenoi-rich leaf tissues. Journal of Plant Biology, 50(1), 60-64. http://dx.doi.org/10.1007/BF03030601

Scheiderbauer, A., Sandernann, H., \& Ernst, D. (1991). Isolation of functional RNA from plant tissues rich in phenolic compounds. Anal Biochem, 197(1), 91-95. http://dx.doi.org/10.1016/0003-2697(91)90360-6

Sambrook, J., Fritsch, E. F., \& Maniatis, T. (2000). Molecular Cloning: A Laboratory Manual. $2^{\text {nd }}$ ed. Cold Spring Harbor: Cold Spring Harbor Laboratory Press, ISBN 0-87969-309-6.

Thompson, J. R., Wetzel, S., \& Klerks, M. M, Vasková, D., Schoen, C. D., Spak, J., \& Jelkmann, W. (2003). Multiplex RT-PCR detection of four aphid-borne strawberry viruses in Fragaria spp. in combination with a plant mRNA specific internal control. Journal of Virological Methods, 111(2), 85-93. http://dx.doi.org/10.1016/S0166-0934(03)00164-2

Vasanthaiah, H. K. N, Katam, R., \& Sheikh, M. B. (2008). Efficient protocol for isolation of functional RNA from different grape tissue rich in polyphenols and polysaccharides for gene expression studies. Electronic Journal of Biotechnology, 11(3), 1-5. http://dx.doi.org/10.2225/vol11-issue3-fulltext-5

Wang, D., Douglas, D., Kreader, C., Dinther, J. V., \& Valdes-Camin, R. (2006). An integrated high-throughput system for mRNA purification and quantitation for use in identifying gene knockdown by RNA interference. Journal of the Association for Laboratory Automation, 11(5), 314-318. http://dx.doi.org/10.1016/j.jala.2006.07.003

Yang, H., Zhang, Z., Du, G., Dai, H., \& Gao, X. (2006). RT-PCR detection of Strawberry mottle virus based on internal control. Acta Phytopathologica Sinica, 35(2), 116-122.

Zhang, J., Wang, X., Yu, O., Tang, J., Gu, X., Wan, X., \& Fang, C. (2011). Metabolic profiling of strawberry (Fragaria $\mathrm{x}$ ananassa Duch.) during fruit development and maturation. Journal of Experimental Botany, 62(3), 1103-1118. http://dx.doi.org/10.1093/jxb/erq343 